Urban Upheaval in India: The 1974 Nav Nirman Riots in Gujarat

Author(s): Dawn E. Jones and Rodney W. Jones

Source: Asian Survey, Vol. 16, No. 11 (Nov., 1976), pp. 1012-1033

Published by: University of California Press

Stable URL: http://www.jstor.org/stable/2643482

Accessed: 11-08-2015 19:01 UTC

Your use of the JSTOR archive indicates your acceptance of the Terms \& Conditions of Use, available at http://www.jstor.org/page/ info/about/policies/terms.jsp

JSTOR is a not-for-profit service that helps scholars, researchers, and students discover, use, and build upon a wide range of content in a trusted digital archive. We use information technology and tools to increase productivity and facilitate new forms of scholarship. For more information about JSTOR, please contact support@jstor.org. 


\section{URBAN UPHEAVAL IN INDIA: THE 1974 NAV NIRMAN RIOTS IN GUJARAT}

\section{Dawn E. Jones and Rodney W. Jones*}

For THE FIRST ten weeks of 1974, the Indian state of Gujarat faced an emergency of locally unprecedented proportions. Waves of riots and political agitation swept through its cities and towns, causing over one hundred reported deaths, many more serious injuries, massive arrests, and the destruction of huge amounts of public and private property. The Nav Nirman ("social reconstruction") movement spread like a firestorm throughout urban Gujarat in January, continued in the face of Army intervention, and subsided only after the leaders secured key political objectives. The most important of these was the overthrow of the state government, partially realized on February 9 when the Chief Minister resigned under pressure from Delhi and President's Rule was clamped on the state, and completed on March 15 when the Prime Minister reluctantly acceded to dissolution of the Gujarat legislative assembly. ${ }^{1}$

The upheaval has since had major repercussions on Indian national politics. The Gujarat riots, together with the anti-government

* This article is based on field work carried out in Ahmedabad, Gujarat, and Delhi between September 1974 and January 1975. We relied heavily on field interviews, supplemented by research in the newspaper clippings files of the Sapru House Library in New Delhi. We wish to express our gratitude to the American Institute of Indian Studies for financial support; to Dr. Amrik Singh of Delhi University for his thoughtful guidance; to Shri K. C. Parikh, Registrar, and Professor Devavrut N. Pathak, Director of the School of Social Science, at Gujarat University for their hospitality and support; and to Dr. Rajni Kothari and D. L. Sheth at the Centre for Developing Societies, Delhi, for comments on an early draft. Others too numerous to mention have been generous in their help. We assume sole responsibility, of course, for the views expressed and any errors that may remain in the final product.

1 An excellent comparative overview of the Gujarat and Bihar movements has just appeared: see John R. Wood, "Extra-Parliamentary Opposition in India: An Analysis of Populist Agitations in Gujarat and Bihar," Pacific Affairs, Fall 1975, pp. 313-334. A good preliminary treatment of Nav Nirman, with additional details, is Ghanshyam Shah, "The Upsurge in Gujarat," Economic and Political Weekly (Special Number, August 1974), pp. 1429-1454; this periodical is hereafter cited as EPW. For a Gujarati language account, see Babulal Dave, et. al., Gujaratnu Lok Andolan (Ahmedabad, 1974). 
movement of Jayaprakash Narayan in Bihar, which they had inspired, were evidently a key factor in Indira Gandhi's decision to declare a national State of Emergency on June 26, 1975. When queried as to whether India's internal stability was really threatened, Mrs. Gandhi replied:

We had a movement in the state of Gujarat, we had a movement in the state of Bihar. ... in Gujarat the members of our legislative assembly were threatened and intimidated and forced to resign. There was violence. Students were not attending college. We had strikes. . . . there was such indiscipline that even government functioning was becoming extremely difficult. ... [the opposition] tried to paralyze the government of ... Gujarat and Bihar. But it is obvious that if this happened on a nationwide scale-and this was what was announced [Narayan had called for a nationwide civil disobedience campaign, to begin on June 29]-there would have been wide-scale violence. . . I I think there was grave internal danger to the country. ${ }^{2}$

While many observers thought that the "grave internal danger" most immediate was to Indira Gandhi's personal power, the prospect of widespread violence paralyzing the central government temporarily should not be lightly dismissed. The salient threat to the Prime Minister's leadership arose from fractures in the Congress party, which a successful replay of the Gujarat rebellion in the urban areas of the Hindi-speaking heartland-clearly Narayan's intention-would certainly have exacerbated. In that event, the Congress party's capacity to govern was also at stake-a matter of more profound concern than Mrs. Gandhi's survival. Our primary purpose for reporting on the Nav Nirman agitation-to explain its origins by uncovering the central role of educational forces-pre-dated the national emergency, but we are struck by the extent to which the Gujarat events were symbolically important in Jayaprakash Narayan's confrontation with the Prime Minister. The memory of Nav Nirman, essentially, is of the capacity of an indignant middle class to paralyze and overthrow elected governments.

Besides being based in the urban middle class, the Nav Nirman agitation exhibited other significant features. Though spearheaded by student activists, who received most press coverage, it was inspired, organized and coordinated by associations of teachers in the colleges and schools. ${ }^{3}$ Underlying the agitation, in fact, was a struggle for power in the educational system between teachers and private institutional managements. The struggle was elevated to the state level in 1973 when

2 NBC, "Meet the Press," broadcast August 24, 1975; reprinted in India News (Washington, D.C.: Embassy of India, September 5, 1975).

3 On this point, our analysis differs from that of John Wood, who argues that "The Gujarat agitation revealed a capacity for spontaneous, localized action, but almost no coordination on a state-wide basis." "Extra-Parliamentary Opposition," p. 323. Our finding is that such coordination existed, if not decisively among students, certainly among teachers' associations. 
Chimanbhai Patel, a former Economics professor and political agent of private college managements, became Chief Minister of Gujarat, and subsequently the target of the 1974 agitation. The Nav Nirman leaders were professedly nonviolent and nonpartisan; while unable to prevent violence, they largely succeeded in resisting penetration by political parties. But political parties and factions did exploit the riots for purposes of their own and thus contributed to the success of the movement. Linkages with the center were important, both in aggravating economic conditions underlying the rioting and in deciding how the government would respond.

The movement gathered its overwhelming force from the broad, largely unorganized involvement of the urban middle and lower middle classes, particularly white-collar employees of private and public bureaucratic enterprises, but also professionals, including journalists, lawyers, and even doctors. Unionized industrial workers remained aloof, but nonunion workers participated sporadically. The affluent classes were uninvolved, except as intermediate targets of the riots, mainly traders and merchants. The immediate causes of white-collar rioting were economic-food scarcities and inflated prices-but frustrations were compounded by the belief that these problems were artifacts of "manipulative politics." Collusion between politicians and businessmen in fixing prices by controlling market supply for mutual profit, and the open use of large sums of money in politics to win elections and to break or make cabinet ministries, were perceived as the underlying causes of economic distress as well as the erosion of middle class influence in government affairs.

\section{Party and Factional Politics in Gujarat}

The 1969 split in the Congress party hastened the ascendancy of manipulative politics in Gujarat; it shattered personal expectations, scrambled group loyalties-sometimes even down to the family and neighborhood level-and impelled much greater intervention by the center in state and local politics. Although the Gujarat Congress $(\mathrm{O})$, led by Morarji Desai and Chief Minister Hitendra Desai, initially survived in the state government, it was toppled in May 1971 by the maneuvers of a former protegé, Chimanbhai Patel. Chimanbhai had defected the previous December to the Congress, the ruling party at the center, along with other dissidents representing the rural middle classes. Chimanbhai's contacts with the affluent farmers, especially with the Patidar caste to which he belongs, were indispensable to the overwhelming Congress victory in the 1972 Gujarat elections. The Congress won 140 out of 168 assembly seats, the Congress (O) only 16, the Jan Sangh 3, Communists 1, and Independents the balance.

Local intra-party rivalries ensured that the new Chief Minister would be chosen in Delhi. Chimanbhai and other local aspirants were 
passed over for a Member of Parliament, Ghanshyam Oza, a Brahman from Saurashtra and senior politician of the old school. Pragmatic, mild-mannered and respectable, Oza was expected to have a good chance to bring unity in the new government. But the Congress assembly party was an unstable amalgam of ambitious men from contrasting political and ideological backgrounds, including former Congress $(\mathrm{O})$ dissidents, Socialists and Communists who were anti-business, and ex-Swatantra party members who strongly defended free enterprise. But ideology was hardly the principal factor in the factional division which crystallized between "loyalists" and "dissidents"; calculations about power were primary, even among those who already shared it.

The "loyalists" supported the Chief Minister, were allied with the Prime Minister at the center, and held a majority in the cabinet. They were led by Agriculture Minister Ratubhai Adani, like Oza a seasoned politician from Saurashtra, and by Education Minister Gordhandas Chokawala and the newly installed party chief Jhinabhai Darji. Chokawala and Darji had been long-standing rivals of Morarji and Hitendra Desai in the old Congress, all four being natives of Surat district. Among the "loyalists" were also two former Praja Socialists in the cabinet and an ex-Communist in the assembly. Leading the "dissidents" at the outset was Finance Minister Kantilal Ghia, himself a businessman who was well-connected with Ahmedabad industrialists. He was supported, covertly at first, by Chimanbhai Patel, Minister of Industries and Planning. They were joined not only by conservative former Swatantra members of the legislative assembly (MLAs), but also by a coterie of leftists, including the former Praja Socialist Dr. Amul Desai, and other MLAs of Socialist and Communist background. While these factions were basically marriages of ambition and convenience, there was one "interest-based" element of cleavage: Jhinabhai Darji and Chimanbhai Patel were rivals for control both of the party organization and the rural classes, with Darji appealing more to the disadvantaged agricultural laborers and Chimanbhai to the prosperous farmowners.

The dissidents, openly led by Chimanbhai after March 1973, overthrew the Oza ministry in June 1973 in a manner that left an indelible public impression upon which Chimanbhai's opponents capitalized in the Nav Nirman agitation. Ostensibly the dissidents argued for new leadership on the grounds of autonomy, saying that Oza had been imposed by the center, not elected by the assembly party. But mercenary appeals-the dangling of ministerships and money-allegedly were what brought waverers into the dissident camp. Both sides engaged in the practice, but the dissidents evidently had the bigger purse. Chimanbhai and Ghia gathered some 70 MLAs and bargained with them until all were ready to declare "no confidence" in Oza when, on June 27 , the press was called in to record it. Oza submitted his resignation immediately. 
But the gymnastics had only begun. Having jointly overthrown Oza, Chimanbhai and Ghia promptly fell apart, each seeking the Chief Ministership. Ratubhai Adani (loyalist) endorsed Ghia, the Ahmedabad millowners favored him, and he secured support in Delhi. Both sides campaigned in the press, each accusing the other of "detaining" (coercing) MLAs and making it impossible to "verify" who supported whom. Oblivious to self-implication, Ghia baldly accused Chimanbhai of having used a slush fund donated by a rich industrialist to purchase defections from the Oza government. Despite Delhi's postponement of elections, Chimanbhai finally won on July 14 by 72 votes to Ghia's 62 , a narrow but absolute majority of the legislative party. Indira Gandhi reluctantly accepted the verdict, and Chimanbhai was sworn in as Chief Minister of Gujarat.

\section{Food and Oil Prices in Gujarat: Chimanbhai's Deal with the Center}

Despite his tarnished public image, Chimanbhai had a reputation for intelligence, decisiveness and organizational talent. Defying the Congress High Command in favor of a local decision won him grudging respect in certain circles. His free enterprise orientation and support of private managements in education made him safe in the view of the business world, and as a "son of the soil" he had the admiration of affluent farmers. His government started briskly, and the attitude of the press was positive, serving to rally support especially when severe floods hit Gujarat in September.

Chimanbhai's troubles stemmed partly from commitments he negotiated with the center. His main goal was to bring about an early settlement of the Narmada river dispute, which had dragged on for over a decade between Madhya Pradesh and Gujarat and was then snagged in a tribunal. As an economist-politician, he dreamed of allocating the river's huge hydroelectric and irrigation potential for planned industrial and agricultural development in Gujarat. Had this materialized under his stewardship, he probably would have become the state's unchallenged leader and a potential contender for power at the center. He was prepared to offer the Madhya Pradesh government a package of financial compensation for submerged land and shares in water and power so generous that he did not see how they could possibly refuse. But to unlock the dispute from the tribunal, he needed action from the center.

The Congress High Command in 1973 was preparing for midterm assembly elections, due in February 1974, in the Prime Minister's home state of Uttar Pradesh. To win their backing on the Narmada issue, Chimanbhai apparently made a deal whereby the Gujarat Congress would provide a handsome sum (our interview information put it at 40 million rupees) to help finance the Congress campaign in U.P. (That finance may have been crucial; the Congress won a narrow majority of 
seats, but with a precariously low $32 \%$ of the vote.) ${ }^{4}$ But Chimanbhai's technique for raising so large a sum was one cause of his undoing.

To raise the money he made a deal with the groundnut oil farmers, merchants, and millers of Gujarat. His part of the bargain was to withdraw government controls from the groundnut oil industry, allow prices to rise, and permit free export of the oil products from Gujarat. These measures enabled the "oil kings" to reap enormous profits, from which they were delighted to subscribe a portion to the election fund of the Gujarat Congress. This deal was risky because groundnut oil is the usual cooking medium in Gujarati middle class households. When its price doubled and it became scarce on the market in October 1973 even after a bumper harvest, the public suspected price-rigging by politicians and traders. In the resulting furor, the blame fell on Chimanbhai. Charges of political and personal corruption in the oil trade loosened the normal Gujarati restraint and set the stage for the Nav Nirman riots. ${ }^{5}$

Chimanbhai's deal with the center produced a second problem, connected again with the U.P. elections. To win those elections, it was imperative to keep food prices down in U.P. But India had suffered droughts and production setbacks in several regions in the previous two years. To ensure the supply of foodgrains in U.P., the center cut its allotments from procured stocks to food-deficit states and funneled what was saved into the fair-price distribution network of U.P. To prevent leakage through the free movement of food grains by wholesalers to areas of high demand, the central government took over the wholesale grain trade in 1973. As a food-deficit state, Gujarat's allotment quota of 105,000 tons a month in early 1973 was cut to 75,000 tons in July, when Chimanbhai took over, and dropped progressively to under 35,000 tons in November and December 1973.

Grain prices soon joined oil in soaring to alarming levels, and this occurred on top of an already astronomical (nearly 100\%) increase in the first six months of 1973. The public had tolerated rising prices under Oza's government, assuming they were effects of the drought, but late 1973 saw improvement in Gujarat's own agricultural production with a doubling in output of rice and bajra (millet) and a quadrupling of groundnuts. Urbanites found this hard to reconcile with continued food price rises. Once again they suspected corruption, but, if so, this was only part of the story. More crucial was a failure of will, for political reasons, on the part of Chimanbhai's government. While

4 "More than anyone else, the Congress had attached great 'domino' significance to Uttar Pradesh, the power base of all the Prime Ministers to date. Had it failed there, its ministries in adjoining Bihar, Madhya Pradesh, Haryana, and possibly Rajasthan might have tottered to a crash, transmitting the party crisis to the Centre before the presidential election in August." MR, "The Elections: Emergence of Regional Forces," EPW, March 16, 1974, pp. 433-436.

5 See the report by N. S. Jagannathan, "Student Power in Gujarat," Hindustan Times, March 5, 1974. 
he acceded to the diversion of grain from Gujarat to U.P.- at least he did not protest it publicly before mid-January 1974 when he was already in serious trouble-Chimanbhai was gambling both on the center's support to contain urban disturbances and the capacity of Gujarat's public grain procurement system to make up for deficits by levies on farmers' surpluses in the abundant harvest expected. But procurement efforts were resisted by the farmers, who concealed their stocks from the authorities, and Chimanbhai was unwilling to risk antagonizing this key constituency. ${ }^{6}$ As N. S. Jagannathan put it, "the government's commitment . . . was half-hearted and contradictory orders-not always written ones-from above made it impossible for the field staff to make a success of the levy." 7 The price of rural pacification, however, turned out to be urban riots and further postponement of a Narmada resolution.

\section{Student and Teacher Associations: Educational Politics}

Artificial scarcities, skyrocketing prices, and political corruption were the issues which fed urban middle class cynicism about politics, conditioned them to riot or tacitly protect those who did so, and drew them into sustaining a movement to overthrow their government. Factional dissidence in the ruling party undermined the government from within - but only after the durability and breadth of the movement became evident. By themselves, and without integrating organizations, the middle classes could not have rioted over food prices and shortages indefinitely or synchronized disturbances in the urban areas throughout the state. Protracting the agitation, instilling it with purpose, and coordinating its various facets were the functions mainly of college students' and teachers' associations.

Widespread involvement by college students may have been, from the standpoint of the authorities, the single most unmanageable feature of the agitation. As the leader of Gujarat's college teachers, K. S. Shastri, put it: "An employees movement can be crushed, but not students. There are no effective sanctions against students. Employees who strike won't get their salaries. But if you close the schools to discipline the students, then they are out on the streets making a nuisance." 8

Students became a major force in Gujarat politics comparatively recently, in the 1970s. Students were active in the Mahagujarat move-

6 Rural politics in this way did have a bearing on the origins of the Nav Nirman riots. There was also rural unrest in South Gujarat, briefly compounding Chimanbhai's difficulties, but resolved well before he was forced to step down. Jan Bremen, "Mobilization of Landless Labourers: Halpatis of South Gujarat," EPW, June 22, 1974, pp. 974-977.

7 "Student Power in Gujarat," Hindustan Times, March 5, 1974. See also Samir Pal, "Hoarders Who Fill Congress Coffers," Hindustan Times, January 30, 1974, and Kuldip Nayar, "Trouble in Gujarat," Statesman (Delhi), February 3, 1974.

8 Interview in Ahmedabad, November 10, 1974. 
ment before 1960, but those with a political bent were coopted by the Congress party and became remote from succeeding generations. Only the Maharaja Sayajirao University of Baroda, because of its integrated structure, has had a university-wide student union since, incidentally, Chimanbhai Patel became its president in 1950. Today that student union draws on a large student body of 18,000 and is a force to be reckoned with in local politics. Elsewhere in Gujarat, student unions are much smaller and are organized within affiliating colleges. Since there are now over 250 such colleges-ranging in size from under 2,000 to as low as 150 enrolled students-student politics has typically been fragmented within small spheres.

Fragmented though college students are, their numbers and corresponding potential for disturbances have expanded enormously along with the system of higher education. In Ahmedabad city alone, for example, the colleges affiliated with Gujarat University have grown in number from 8 in 1950 to 56 in 1974, enlarging the city's base of college and university students more than twelvefold, from about 4,000 to over 50,000 . In the state as a whole, by 1974 college students numbered about 160,000. Most student unrest has revolved around the specific grievances of student life, fees, curriculum and examinations, the language of instruction, concessional bus fares, food and hostel living, and more trivial problems. What makes student grievances explosive, however, is growing frustration over the declining prospects for finding suitable jobs.

Since 1967, when college students in Ahmedabad demonstrated successfully to roll back a hike in tuition fees, there have been sporadic efforts to concert student politics on a broader basis. But not until the Ahmedabad riots of July 14-16, 1973, did college students set up a coordinating committee of student unions in the city. That committee organized a demonstration to lampoon the MLAs who were then being bought and sold in the struggle for government power and to demand student representation in the governing bodies of Gujarat University. Statewide coordination of student action was produced for the first time the following January, under Ahmedabad's Nav Nirman Yuvak Samiti (Reconstruction Youth Committee). Student coordination remained loose even then, but the heritage of student decentralization in unions may have been, paradoxically, one of the Nav Nirman movements greatest strengths. There was no exclusive circle of student leaders, no single authoritative organization, that could be identified, corrupted, or effectively repressed.

Much more effectively organized, as the disciplined but less visible core of the movement, were the teachers of Gujarat, especially the college teachers. Primary school teachers employed by the Ahmedabad municipal government had been united since 1929 in the Shikshak Mandal (Teachers' Association), and similar associations were formed later in Baroda, Surat, Rajkot and other towns. In 1947, these associa- 
tions gained trade union recognition under the Industrial Disputes Act; their primary concern has been with pay and related service conditions. The latest official figures showed 85,250 primary teachers in Gujarat, but by 1974 their number was probably in excess of 100,000 , with about half in urban locations. The Ahmedabad Shikshak Mandal had a membership of 3,584 in 1974 , about $75 \%$ of those eligible. A federation of municipal school teachers associations linking those of Ahmedabad, Surat, Baroda, and Rajkot was formed in 1972, with headquarters in Baroda. ${ }^{9}$

Gujarat's secondary school teachers numbered 26,300 in $1968-69$, and probably over 30,000 by 1974 , with at least two-thirds in urban centers and most in the employ of private managements. The Ahmedabad Secondary Teachers Association was founded in 1937; counterparts followed in Kaira, Baroda, Surat and Bhavnagar, and the Gujarat State Secondary Teachers Federation was established in 1947. Recognized by the government, but not as a trade union, this federation now contains 20 units, affiliating all districts but Bhavnagar. In the districts of Ahmedabad, Baroda and Surat, the cities and rural areas each have separate units. The federation's membership includes about $43 \%$ of those eligible. In Ahmedabad city, about 2,400 (80\%) of the secondary teachers were association members. Units of this federation in the major cities of Gujarat were among the most important organizational underpinnings of the Nav Nirman agitation.10

Less numerous but central in the leadership of the movement were college teachers. College and university teachers' organizations are a recent development in Gujarat, dating back only to 1962. In that year, the two largest and most active associations were formed, the Gujarat University Area Teachers Association (GUATA) based in Ahmedabad and the Baroda University Teachers Association (BUTA). GUATA spans the largest university. Until 1967, Gujarat University was the only statewide affiliating university, and today it still presides over about $60 \%$ of the affiliated colleges of Gujarat. Consequently, in 1974, GUATA was the dominant association of its type, with 2,300 members, as against about 900 in BUTA. As colleges formerly under Gujarat University were reaffiliated in 1967 with the new Saurashtra and South Gujarat Universities, former members of GUATA founded new associations, SGUATA in the south (with a current membership of about 500), SUATA at the Saurashtra University headquarters in Rajkot, and the Bhavnagar Pradhyapak Pariwar on Saurashtra's other campus (the two together contain about 1,000 members). The teachers at Sardar

9 Interviews with Balwantrai Dixit, President of the Ahmedabad Shikshak Mandal, and Rajendra Shah, General Secretary of the Ahmedabad Municipal Servants Association, in Ahmedabad, November 22, 23, 1974.

10 Interview with Gajendra Bhrambhatt, a Secretary of the Federation and President until recently of the Ahmedabad Secondary Teachers Association, Ahmedabad, November 18, 1974. 
Patel University in Kaira district founded SPUATA (450 members), a small unit (75 members) existed at Gujarat Vidyapith, the Gandhian university in Ahmedabad, and the postgraduate faculty of Gujarat University possess GUTA (100 members).

A peak organization known as the Gujarat State Federation of University and College Teachers Associations (GSFUCTA) was founded in October 1972 to coordinate the various associations in a campaign then underway for university reform. GSFUCTA's total membership today comes to about 5,275, though there are about 700 members of the statewide Government Teachers Association who cooperate, albeit informally, with GSFUCTA, giving the college and university teachers of Gujarat an effective strength of about 6,000.11 During the agitation, K. S. Shastri, of Bhavans College in Ahmedabad, was President simultaneously of GUATA and GSFUCTA.

While status considerations tend to keep college and university teachers apart, they have begun to cooperate in recent years in the face of similar problems arising from the way private educational institutions are managed. The most common complaints of teachers in private institutions are about job insecurity, victimization, and "subtracted salaries"-that is, a situation in which the pay a teacher receives is much less than the figure appearing on the salary receipt he signs. Such complaints have been endemic in the schools, but became common in the colleges only after 1960. Starting in that year, the expansion of higher education accelerated, for commercial and political reasons, and large numbers of new colleges were founded in the cities and district towns. The difficulties experienced by college teachers in the newer colleges were either a product of commercialized operations-the cutting of costs to squeeze out profits-in certain heavily enrolled city colleges, or of poor college financing and management, a chronic problem in lightly enrolled district institutions.

These problems encouraged college teachers to organize and produced conflict between teachers and managements over administrative power in the educational system. While demands for government takeover of secondary education had been aired, the reform proposals of both college and secondary teachers have come to focus on means of making private managements accountable to "autonomous bodies" in which teachers are adequately represented and sit as equals with private managers and government officials. The secondary teachers sought to establish between the Department of Education and the schools a new Secondary Education Board constituted as a corporation. This was provided by the Gujarat Secondary Education Act of 1972, approximately as demanded.

Similarly, the college teachers sought revisions of the Gujarat Uni-

11 This membership comprised about $75 \%$ of the approximately 8,000 college and university teachers employed in Gujarat in 1974, a high participation rate. 
versity Act to convert "affiliated" colleges into "constituent" colleges in order to transfer personnel questions from the control of private managements to the university, and also to place enough teachers' representatives on the university governing bodies to balance private managements. One aspect of the old university act was the absence of a ceiling on the number of college principals in the Senate; as the number of affiliated colleges increased in number from 30 to 147, principals, the agents of private managements, came to dominate the Senate. Chimanbhai Patel's control of the university was based on the fact that many private managements were indebted to him for help in getting their institutions started, and the principals in those institutions were obliged to follow Chimanbhai's bidding. Partly because of Chimanbhai's influence in the government the GUATA-led college teachers had to exert increasing pressure for five years before they finally succeeded in extracting the Gujarat University (Amending) Act from the government in 1973-not long before Ghanshyam Oza's overthrow.

What outraged GUATA most was Chimanbhai Patel's continued interest in university politics after he became Chief Minister in July 1973. GUATA leaders had hoped that once Chimanbhai's ambitions were fulfilled, he would stay aloof from the internal affairs of Gujarat University. But in the October 1973 university elections of the ViceChancellor and university governing bodies, Chimanbhai intervened to help win the Vice-Chancellorship for a protegé and to defeat the GUATA slate of nominees from the Court (Senate) to the Executive Committee (Syndicate).12 When GUATA leaders became aware of Chimanbhai's lobbying, they informed friends of the Chief Minister that, if his efforts did not cease, "Gujarat University campus would become his graveyard."

These university elections were important in another respect-they were the first in which students vied for 12 seats on the Court and representation also on the Boards of Studies and other university bodies. Students elected to the Court suddenly found themselves solicited by GUATA, GUTA, private managements and others for their support in the elections of the Vice-Chancellor and Executive Committee, and they acquired a new inflated sense of importance. One postgraduate student, Manishi Jani, was elected to the Executive Committee with the help of GUATA. Jani was to become the President of the Nav Nirman Yuvak Samiti (NYS), and most of the other office bearers of that organization were drawn from among the students elected to the Court of Gujarat University. ${ }^{13}$

12 The names of these bodies were revised by the amended University Act of 1973.

13 See V. Gangadhar, "Gujarat: 'Sick' University," The Illustrated Weekly of India, November 24, 1974, pp. 17-19. 


\section{Agitation Phase One: The Overthrow of Chimanbhai}

In the Nav Nirman movement, the middle class shared with students the bulk of police confrontations, but the teachers provided most of the guidance and coordination. Student rhetoric was filled with grandiose pledges for the reconstruction and purification of politics, and implementation of various proposals for distributive justice, but the demands of GUATA and GSFUCTA were more down to earth. Without discouraging student expressions of idealism, the college teachers inspired the concrete demands for the ouster of Chimanbhai and the assembly and kept the movement from drifting from these central objectives.

The efforts to distract were most certainly there. The Jan Sangh party, for example, promoted anti-price rise demonstrations to embarrass the Congress, but withdrew from the agitation when Chimanbhai Patel, with whom Jan Sangh leaders apparently sympathized, became a specific target. Similarly, while Congress dissidents in Chimanbhai's cabinet tacitly suported the demonstrations against Chimanbhai, they later sought desperately to prevent the dissolution of the assembly. It is really a measure of the independence of the Nav Nirman movement from political parties, qualified only by the permeability of the students in the agitations' last phase, that it was at no point successfully derailed by party overtures or machinations.

The Jan Sangh party was partly responsible for the climate of tension in Gujarat from which the main anti-price riots began in Ahmedabad. That party had started a campaign of bundhs (shut-downs) in Saurashtra region cities against traders suspected of hoarding foodgrains as well as against alleged police atrocities. Rajkot had serious riots on December 3, and a month later Jetpur and Porbander were similarly affected, causing the authorities to close the schools there. In this atmosphere, events at two engineering colleges triggered the main agitation and drew students in.

Late in December 1973, students went on a rampage at the Morvi engineering college in Saurashtra, protesting against higher fees for hostel food-the result of a government economy move. On January 4, 1974, students at the L. D. College of Engineering in Ahmedabad, adjacent to the Gujarat University campus, also rioted against higher mess charges, burned the canteen, and attacked the rector's residence. Reprehensible though this may have been, the police response ordered by the Chief Minister was imprudently harsh. The State Reserve Police (SRP) - a riot control force with a reputation for brutality-invaded the dormitory to arrest suspects. Several students were severely beaten in the process, some 336 students ( $25 \%$ of the student body) were jailed, and the college was shut down.

Other college and university students convened immediately at the 
university campus and formed an action committee to seek the release of those arrested and to press both for the resignation of the Education Minister and a reduction in mess hall charges. They marched in a body of a thousand on the nearby police station to get the students held there released, and then to the Congress party headquarters, but all to no avail. After the Chief Minister relayed a message that he was too busy to meet them, the student committee called for a strike to shut the colleges and secondary schools on Monday, January 7. On Sunday, the 6th, during observance of "anti-police day" (called by the Jan Sangh to protest police firings in Saurashtra), trouble broke out in the congested, walled city of Ahmedabad. Gangs of youngsters began stoning municipal buses, and that night mobs attacked and looted a number of shops selling foodgrains and cooking oil. On Monday, most colleges and schools stayed closed, students roamed the streets blocking public transport, and a number were injured or arrested in battles with the police.

Evidence of broader middle class involvement in the riots also came on Monday when the August 14th Committee (AUGCOM) announced an "Ahmedabad bundh" for January 10 to protest high prices and alleged police brutality. AUGCOM had been created in August 1972 as a citywide umbrella organization of about 80 trade unions, most of which covered white collar employees of the state and municipal governments, the State Bank, nationalized banks, the Life Insurance Corporation, and primary and secondary schools. In the wake of the urban riots, the Chief Minister called a meeting with student leaders to offer pacifying concessions, but refused to release students who had rioted, and the negotiations therefore failed.

Students met on January 9 in the university hall, where they pledged to return to their studies only after essential commodities reappeared in adequate supply in the markets, thereby linking their movement with popular economic grievances. They appealed for the support of students in other Gujarat cities. GUATA cautiously and obliquely entered the movement at this stage, deciding in a general meeting the same day and at the same place to start a campaign against the pro-management policies of the Vice-Chancellor. GUATA expressed sympathies for the student movement and endorsed the call for an Ahmedabad bundh. The first police firing in Ahmedabad occurred on the same day to disperse a mob looting grain shops; after two buses were burned, the government began systematically arresting provocateurs, and a curfew was imposed on the city that night.

The shut-down of Ahmedabad was nearly total on the 10th. Only the textile mills operated normally, as the organized working class stayed clear of the disturbances. Sporadic incidents of stone throwing evolved into raids on shops and municipal milk booths, and battles between crowds and the SRP ensued, provoking firing at 20 locations and the use of tear gas at many others. Confrontations escalated rap- 
idly in the walled city, which is divided into traditional neighborhood units known as pols. Built as enclosures, the pols are crammed with three and four-story buildings, the outer periphery of which are continuous walls. From the main streets, pols have one or two entrances with heavy gates, which can be locked by the residents in the event of danger outside. When the police entered the narrow lanes of the pols, they became targets for stones and flaming rags thrown from balconies and windows, and their discipline broke down. The rioting continued intensely for two more days. Parallel disturbances in Baroda were equally serious, and the riots spread to nine smaller cities.

January 10 was a landmark day for two other reasons. On that date, the college students of Ahmedabad formally established the NYS (coordinating committee), elected officers, and declared a program of broad idealistic objectives, vowing to wage a nonviolent struggle to cleanse and rebuild a society corrupted by politicians. A second important development was the injection into the campaign of the strategic demand for the resignation of Chimanbhai Patel, a specific, attainable goal promoted by the college teachers in Ahmedabad and Baroda and quickly picked up by students.

On January 14, the rioting subsided as the kite-flying festival of Sankranth distracted the youth of Gujarat. But fissures now appeared in the state government. Three of Chimanbhai's Ministers had already expressed subtly phrased sympathy with the student's efforts to force foodgrain hoarders to release their stocks, and 25 dissident Congress MLAs urged the Prime Minister to impose President's Rule on Gujarat. To dampen public criticism, Chimanbhai fired the Food and Civil Supplies Minister as a scapegoat for the government's failure to provide adequate food and controlled prices. In the lull that followed, educational institutions reopened on the 16 th.

Perceiving that the movement was on the verge of petering out, GUATA leaders came to the forefront on the 16th to revive the agitation. They met and declared their support for the "just demands" of the students and indicated their intention to take an active part in the agitation. The NYS, thus encouraged, called for an indefinite closure of the university and colleges, and clashed with police in efforts to shut down individual colleges by force. On the 17 th, when the Vice-Chancellor declared he would keep the university open, students gheraoed (forcibly confined) him in his office and burned furniture and records in the administration building.

By this time the main leaders of the NYS had been arrested, so there was uncertainty about who was really in charge. Chimanbhai Patel took this opportunity to arrange a meeting on the 18th of college principals and carefully screened student union general secretaries, hoping to bypass those NYS leaders who were behind bars. Despite the protests of a minority, he secured the signatures of more than half the general secretaries on an agreement to withdraw their strike and allow 
the peaceful reopening of colleges, in exchange for the release of the NYS President and Secretary; further problems were to be negotiated between the government and a similar committee of student union secretaries. The agreement, which would have had the effect of atomizing the student movement, was sharply repudiated by the newly freed NYS leadership, and most of the union secretaries recanted in a meeting on the 19th; they affirmed that the strike would not be lifted until Chimanbhai Patel resigned. The government promptly rearrested those NYS leaders it could locate, together with certain teachers and AUGCOM leaders; other student leaders had already gone underground.

In the meantime, local Nav Nirman committees had begun sprouting in other cities of Gujarat, and the volume of riots intensified once again, with serious bloodshed in Surat and Rajkot. By the 21st, the rioting had appeared in one form or another in all the important urban centers of the state, and the situation in Ahmedabad again deteriorated after a use of force by police against a peaceful procession of teachers and students from H. K. Arts College, in the course of which women students were injured. Mass fasting was organized and leading college professors resigned from the Congress party in outrage. AUGCOM called for a bundh throughout Gujarat for January 25, and various organizations endorsed it. On the 23rd, GUATA held a general body meeting attended by about 1,000 members at which it was decided to join the agitation officially and to cooperate openly with the NYS and AUGCOM. GUATA went on record demanding the resignations of the Chief Minister, the government, and the entire assembly. The real political objectives of the movement, by this act, were brought out in the open. For GUATA, the crucial problem now was to hold the movement to those objectives.

As precautionary measures, the government reinforced the state police with the Border Security Force and the Central Reserve Police, and imposed curfews on 106 cities and towns on January 25, Gujarat bundh day, but by the end of the next day the escalation of mob activities had brought the death toll of the riots to 42. On Republic Day, the 26th, battles between crowds and the police became so intense in Ahmedabad that the local police force showed signs of rebellion, unwilling any longer to attack women and children or face the bombardment of kerosene-soaked rags in the pols. As law enforcement collapsed, some thousand Ahmedabad shops were pillaged in the course of one day. On the following night, Chimanbhai held an emergency cabinet meeting and announced that Indian Army units were being called in.

Violence subsided everywhere but in Surat as the Army appeared on the streets of Ahmedabad on the 28th, and emergency shipments of food which Chimanbhai had desperately requested from the center finally began to arrive in the city. The Army was respected in Ahmedabad; its suppression of the 1969 communal riots had been firm and 
effective. Since the popular violation of curfews would be far more risky now, GUATA, the NYS and press sympathizers spread the word that the Army was to be welcomed. Instead of stoning and abusing the soldiers as they had the police, people garlanded them with flowers and plied them with tea and sweets, a most ingenious and disarming method of flaunting the curfew. Peace was maintained for almost a week. This gave the Chief Minister a chance to make overtures to the teachers. He announced measures satisfying certain longstanding pay scale and cost-of-living demands of GUATA and GSFUCTA, and he sent out feelers to GSFUCTA leaders, promising to release MISA detenus if the teachers would agree to negotiate. ${ }^{14}$ Chimanbhai's offer, though calculated to divide teachers, indicated he recognized, finally, where the central impetus of the movement lay.

Before the components of GSFUCTA met on February 3 to consider Chimanbhai's offer, GUATA leaders had hammered out a finished proposal to ward off a potentially divisive debate between militants and conservatives in the associations and to defuse an anticipated problem in their relations with the NYS and students. The teachers' biggest problem was to reassure the students, who were now apprehensive that the examinations scheduled for March would be held. GUATA could allay student anxieties only by supporting an examination boycott, which it did, but in a complex way. Arguing that the violence of the agitation was a product of the government's suppression of peaceful demonstrations, by prohibitions and bans, the teachers would remain on indefinite strike until the bans were lifted and all those arrested under MISA were released. Only then would teachers return to the classroom. But the teachers would still boycott examinations until Chimanbhai's ministry was dismissed and the assembly dissolved. With the continued solidarity of students and teachers thus reinforced, GUATA's proposal was ratified by GSFUCTA; this action launched a new program in which teachers started mass fasting, led peaceful processions, and courted arrest openly by defying the bans on meetings and processions. ${ }^{15}$

In fresh rioting that swept across Gujarat after February 4, campaigns for the resignation of government ministers and MLAs added a new theme. Though backing from the center remained firm until

14 Free Press Journal (Bombay), February 2, 1974. MISA stands for Maintenance of Internal Security Act, used on a wide scale for "preventive detention" since 1971 when its predecessor, the Preventive Detention Act, lapsed.

15 An intriguing feature of this program was the "death knell" of Chimanbhai organized by GSFUCTA, a tactic of "coordinated spontaneity." At precisely 8:00 p.m. on February 4, as darkness settled on the city of Ahmedabad, thousands of persons climbed out on the roofs of their houses and began beating thalis (the metal trays used for meals) as is the local custom at funeral ceremonies. Fireworks were added to the din and it carried on far longer than the prearranged 10 minutes. It spread elsewhere in Gujarat cities, even to the new capital in Gandhinagar, where a Minister was heard to remark, "now it is clear, the government must go." See the lengthy reports in Free Press Journal, February 5, 1974. 
February 8, Chimanbhai was visibly shaken by the popular fervor, but he was determined to ride out the storm and "to establish rapport with the people, particularly the teachers." 16 Jhinabhai Darji, the party chief, opposed Chimanbhai openly on the 4th, pleading in Delhi for Chimanbhai's removal. When this move failed, four dissident ministers in Chimanbhai's cabinet presented him on the 7th with an ultimatum demanding his resignation. ${ }^{17}$ Chimanbhai instantly sacked them, but the erosion of his government was now indisputable. The center supported Chimanbhai on the ground that the "constitutional machinery" was intact-i.e., that he held the confidence of a majority in the legislative party, about 90 of the 140 Congress MLAs. This was true, primarily because Chimanbhai's rural-based allies remained loyal, untouched by what was essentially an urban rebellion.

But the end soon came amidst what looked like a comedy of errors in Chimanbhai's government, and possibly bureaucratic sabotage. H. R. Gokhale, the Union Law Minister, was sent to Ahmedabad on the 7th to make a fresh assessment of the political situation in Gujarat. With a curfew in effect, Chimanbhai arranged for selected teachers and students to meet with Gokhale, and they evidently informed him that the disturbances were caused by small minorities of disgruntled individuals. Despite the curfew, GUATA managed the following morning to organize a large procession to march on the Governor's residence, where Gokhale was staying. Though the police stopped the procession some distance away, they permitted a message to reach Gokhale, and he ordered that the leaders be admitted to his presence. The GUATA spokesmen convinced Gokhale that he had not heard authentic views the night before because the real student representatives were underground or in prison.

Gokhale got the Chief Minister on the phone, insisted that the NYS leaders be released and brought to him, and directed that the police provide safe conduct to underground leaders in the event any arrived to meet him. But when two NYS leaders who had been in hiding from the police turned up, they were promptly arrested by the police. When members of the procession blocked the police wagons, the police attacked with canes. Maganbhai Barot, the new state Education Minister, intervened, but, apparently unrecognized, he too was struck by the police. The commotion brought Gokhale outside, and he ordered the students released, but Barot announced his immediate resignation from "this terrorist government."18 This incident clinched things in a way no discussion could. Gokhale packed up and flew back to Delhi on the morning of the 9 th. By noon of the same day, Chiman-

16 Quoted in the Statesman (Delhi), February 7, 1974. The emphasis is ours.

17 The ministers were Dr. Amul Desai (Finance), Divyakant Nanavati (Law), Amarsingh Chowdhury (Social Welfare), and Navinchandra Ravani (Planning)-all of whom had helped Chimanbhai overthrow Oza. Times of India (Bombay), February $8,1974$.

18 Hindustan Times, February 9, 1974. 
bhai got a stern phone call from New Delhi, and several hours later his resignation was public knowledge. The Gujarat Assembly was suspended and President's Rule took effect simultaneously.

\section{Agitation Phase Two: Assembly Dissolution}

Chimanbhai's ouster marked the midpoint of the agitation, not its end. In the next five weeks, the death toll doubled to just over 100. The central government resisted the demands for the dissolution of the assembly until March 15, foreseeing this would be a troublesome precedent, and because it might have an adverse effect on the midterm elections in U.P. and Orissa just two weeks off. But the demand for assembly dissolution became nearly irresistible after Chimanbhai's overthrow, partly because new political forces joined in and expanded the agitation. The Adani-Darji faction naturally opposed dissolution, but the Congress (O) and Jan Sangh parties now openly favored it. Moreover, Chimanbhai Patel's supporters entered the agitation, initially to confuse its purposes, and to build a student following. Chimanbhai continued maneuvering until February 26, trying to get the Prime Minister to introduce a new government under the leadership of an ally, Thakorbhai Patel, of Baroda. But after this effort failed, on March 1 Chimanbhai was expelled from the Congress for defying the High Command's instruction to relinquish the leadership of the legislative party. He subsequently formed a new party, the Kisan Mazdoor Lok Paksh (Farmers' Workers' People's Party), or KIMLOP, and led his own dissolution movement!

The public response to the announcement of Chimanbhai's resignation on the 9th was euphoric; people poured into the streets, and dozens of victory processions were organized. But these popular celebrations turned ugly and violent as hoodlums entered and disrupted them, evidence to some that Chimanbhai was seeking vengeance. The looting of shops, arson and mob attacks on police resumed on February 9, with fresh police firings, deaths and many injuries in Ahmedabad and Baroda in the next two days. Fearing that their movement was about to be subverted by political elements, the leadership of GUATA and the NYS began a "fast for normalcy" on the university campus in Ahmedabad. They ended the fast on the 12th, as conditions temporarily improved, having been joined at this stage by Sarvodaya leaders Jayaprakash Narayan and Ravishankar Maharaj.

The pressure in the second phase focused on Congress politicians -in the assembly, party organs, and municipal councils-to compel massive resignations; it finally succeeded in getting 95 MLAs, more than a majority of the 168 member assembly, to resign. The 16 Congress (O) MLAs resigned as a bloc on February 15, but securing the resignation of other MLAs was more difficult. Though the original leaders of the movement continued to urge nonviolent methods of protest, mob actions against MLAs became aggressive and violent, and 
the clashes between students, crowds, and the police escalated once again. Ahmedabad was paralyzed on the 18th by police firings and riots hinting of communalism. The same day, GUATA called off its strike and college teachers began reporting in their institutions-to carry on the movement from within-at the cost of some misunderstanding among students, who were still worried about having to face examinations.

The NYS leaders called for a bundh in Ahmedabad on the 19th, and it was partially effective. On the 20th, the rioting resumed in Ahmedabad with a vengeance, and spread to the other districts of north and central Gujarat, and once again to Saurashtra. Gujarat University decided on February 23 to postpone the examinations and to close the university and affiliated colleges indefinitely, freeing students to promote the movement with abandon. Resignations of MLAs began to flow, reaching 64 on March 6, when the violence tapered off.

After the results of the U.P. elections became known on February 28-a narrow victory for the Congress-one of the reasons for Delhi's wavering disappeared. Unable to tame Chimanbhai, who was now using the movement for his own purposes, the options available to the center were limited. But the Prime Minister, despite efforts at compromise by intermediaries, refused to dissolve the assembly in the face of coercion. She sensed that it would fuel opposition attacks against factionally unstable governments in other Indian states and guessed, correctly as it turns out, that the Congress would have difficulty winning fresh elections in Gujarat. ${ }^{19}$ The central government took a firm position, hoping the rioting would run run its course, Congress MLAs were instructed to stand fast, and efforts were made to divide the NYS student leadership in order to cripple the movement.

The final spurt of violent agitation erupted in the second week of March. On the 7 th, in their one and only demonstration of sympathy, 150,000 textile and other industrial workers stayed home from work on the instructions of the pro-Congress $(\mathrm{O})$ National Labour Organization of Ahmedabad. On the 11th, Morarji Desai began a "fast unto death" in Ahmedabad against the center's reported move to "crush the popular agitation," which had begun with the arrest in Delhi of 200 NYS lead-

19 State elections were held in June 1975. Despite extensive personal campaigning by Indira Gandhi in Gujarat, the Congress (R) was defeated by the Janata Front, an electoral coalition of the Congress (O), Jan Sangh, and several smaller groups. With one seat undeclared, the Front won 87 of 182 seats, and formed a government, with the support of Independents, under the leadership of Babubhai Patel, a senior Congress $(\mathrm{O})$ politician elected from Sabarmati constituency in Ahmedabad. The Congress (R) obtained 75 seats, and Chimanbhai's KIMLOP got only 13. Chimanbhai Patel lost his own seat. The Statesman Weekly (Overseas Edition) June 21, 1975; Marcus F. Franda, "The Gujarat Election, 1975," (American Universities Field Staff, South Asia Series, XIX:9, 1975), pp. 1-13; and Ghanshyam Shah, "The Gujarat Assembly Election in India," Asian Survey, XVI:3 (March 1976), pp. 270-282. The Janata Front Ministry was forced to resign in early 1976 when it lost a majority in the Legislative Assembly. 
ers, supposedly there to negotiate with central leaders. On the 12th, the now typical cycle of mob violence and police firings disturbed Ahmedabad and Nadiad. On the following day, NYS officers left in Ahmedabad announced new agitation plans to gherao Members of Parliament, harass MLAs and their families, and stop all forms of public transportation in the state. Further deaths from police firings followed in Ahmedabad and Anand as these plans were put into effect. But the decisive factor was the continued resignation of MLAs-against the directives from the center. On March 14, the number crossed the majority mark of 85 , including the very crucial resignation of Ghanshyam Oza, the former Chief Minister and protegé of Indira Gandhi. The dissolution of the assembly was announced the next day.

In the aftermath of dissolution, the student movement fell apart in dissension. When the schools reopened, the NYS leaders won one final victory-the cancellation by the university of examinations that year, and the award of automatic promotions for all students except those graduating in the final secondary or college years. Students pressed for this parochial objective over public opposition and against the advice of the GUATA leadership. It turned the press and middle class opinion against the students, souring their previous accomplishments. By the time the summer vacation arrived, the quarreling that had surfaced among student leaders destroyed bonds of amity and cooperation, stalled the momentum of the NYS, and undermined its stated program for continued social and political reform. The absence of experienced leadership and disciplined organization, though advantageous for the spontaneity of the uprising, now showed as a critical weakness. Some students still resisted the favors of politicians and parties, but others had become susceptible to their blandishments.

\section{Perspectives and Conclusions}

It is tempting in the wake of dramatic political events to exaggerate their importance or to ascribe to them unwarranted uniqueness. That temptation is unusually strong in the case of Gujarat's Nav Nirman movement because it has not only been contrasted with Gujarati norms but also characterized by its own moralistic rhetoric-as idealistic, selfsacrificing action by a newly aroused student cadre, striving to purge politics and society of corruption and to secure a fair deal in the market place for classes in distress. While such aspirations were no doubt sincerely felt by many participants, taking them at face value betrays a misunderstanding of the actual balance of forces operating in the larger environment and probably explains the backlash of cynicism that surfaced later when inflated reformist expectations were not realized.

Viewed historically, the Nav Nirman movement hardly seems so dramatic or unique. Leaving the independence struggle aside, violent agitations have been a recurring feature of Indian politics, even if their 
frequency has increased in the last ten years. If urban middle class rebellion is a departure from Gujarati tradition-itself a debatable point -it has been a chronic force in Bengali political disturbances and probably an underlying factor in a whole series of states reorganization movements dating back to 1952. Although most student rebellions are local phenomena, there is a precedent for student leadership in the overthrow of a state government in Orissa ten years earlier, and large scale student agitation was prominent in the Tamil linguistic agitation against the imposition of Hindi in 1965 and in the Telengana and Andhra statehood movements in the 1970s. There is even a precedent in Kerala in 1959 for the overthrow of a state government by a coalition of forces using private power in higher education as the key issue.

After these parallels have been acknowledged, however, a distinctiveness to Nav Nirman remains. It did not possess the natural mobilizational advantages of sectional issues - the linkage between Gujarat and the elections in U.P. was not widely perceived at the time-yet the agitation spread throughout the urban areas of the state. Unlike most political disturbances (except perhaps those of an explicitly communal nature), Nav Nirman began and remained remarkably free of pressures from political parties and factional interests in state politics. It was singular, above all, in the central inspirational and organizational role of college and secondary school teachers, who maintained within their own associational front extraordinary unity and self-discipline, orchestrated the movement throughout urban Gujarat, and focused its objectives resolutely on the ouster of the Chief Minister and the legislators whom he had so resourcefully manipulated. Student resilience and cohesion, such as it was, was a reflection of that of the teachers. Nonviolent leadership by men of learning, however political its origins in other respects, was not only the original source of the idealistic rhetoric of social reconstruction but also helps to account for the legitimacy the movement achieved in the eyes of the urban middle classes of Gujarat. In these respects, Nav Nirman is without a major precedent in Indian politics. It may nonetheless be the forerunner of future revolts of the "salaried masses," in which broadly-based, nonpartisan, white-collar or professional associations take leading parts in protest politics. And it may be an indication of the beginnings of subconscious urban reaction to the ruralization of Indian politics, which has now come to dominate the political landscape.

The Gujarat movement had broader political repercussions partly because its political objectives, in the final analysis, were resisted and finally capitulated to by the central government after the upheaval had become protracted, had gained national attention, and had become a symbolic test of will and endurance. Its significance was enhanced by Jayaprakash Narayan who perceived-or perhaps misperceived-in it a model for a Sarvodaya crusade against the Congress government in 
Bihar. Nevertheless, Narayan's call evoked a response in mid-1974 that put the Bihar state government under considerable pressure so that it required bolstering from the center.

When the Prime Minister was faced in June 1975 with a court verdict of electoral malpractice, she sensed that it would provide the opposition with a needed catalyst for large urban demonstrations in north India which, she may have feared, might reach unmanageable proportions as they had locally in Gujarat the year before. While it is hardly likely that Nav Nirman could have been replicated with its Gujarat intensity on so broad a basis, even a pale version would have compounded her new vulnerabilities. Hence, the Emergency was invoked as the most decisive legal means available for shielding her government from attack in the streets, serving also to deflect the worst effects of dissidence in the Congress parliamentary party. Would the outcome have been different, one might ask, if Narayan and his colleagues had not rushed in to attack, but had instead watched and waited? In the absence of the satyagraha ultimatum, the Prime Minister would have been denied so plausible a basis for seizing the emergency procedure. She could have done so anyway, of course, even if it had to be on narrower grounds, but in that case she might have been compelled in her subsequent maneuvering to be more cautious, adroit, and sophisticated, and perhaps gentler on the parliamentary tradition and free press.

RODNEY W. JONES is Assistant Professor of Government at the University of Texas, Austin. DAWN E. JONES holds a doctorate in Education from Columbia University Teachers' College, New York. 